\title{
Novel Polydentate Macroacyclic Schiff Base Ligands Based on 2,6-Diformylphenol
}

Yulia S. Kudyakova, ${ }^{@}$ Yanina V. Burgart, and Victor I. Saloutin

Dedicated to Academician Oleg Chupakhin on the occasion of his $80^{\text {th }}$ birthday

I.Ya. Postovsky Institute of Organic Synthesis, Ural Branch of the Russian Academy of Sciences, 620990 Ekaterinburg,

Russian Federation

${ }^{\circledR}$ Corresponding author E-mail: kud@ios.uran.ru

[1+2] Condensation of 2,6-diformylphenol (1) with ethyl-2-[(2-aminophenyl)aminomethylidene]-1,3-dicarbonyl compounds (2) resulted in new macroacyclic bisazomethines 3 having 2-hydroxyphenyl spacer. They are capable of regulated selective modes of mono- and binuclear complexes 4, 5 with $3 d$ metal ions in proper conditions. Crystal structure of $\mathbf{4 d}$ was confirmed with X-Ray data. A moderate tuberculostatic activity of Schiff base ligands $3 \boldsymbol{c}, \boldsymbol{d}$ is reported.

Keywords: Schiff bases, 2,6-diformylphenol, condensation, tuberculostatic activity, 3d metal complexes.

\section{Новые полидентатные макроациклические основания Шиффа на основе 2,6-диформилфенола}

\author{
Ю. С. Кудякова, ${ }^{@}$ Я. В. Бургарт, В. И. Салоутин
}

Посвящается академику РАН Олегу Николаевичу Чупахину по случаю его 80-летнего юбилея

Институт органического синтеза им. И.Я. Постовского УрО РАН, 620990 Екатеринбург, Российская Федераџия

@E-mail: kud@ios.uran.ru

В результате [1+2] конденсаиии 2,6-диформилфенола 1 с этил-2-[(2-аминофенил)аминометилиден]-1,3дикарбонильньми соединениями 2 получень новые макроациклические бис-азометинь 3 с 2-гидроксифенильным спейсером, способные к регулируемому селективному формированию на их основе моно- и биядерных металлокомплексов 4, 5 с катионами переходных металлов. Выявлено умеренное туберкулостатическое действие синтезированных лигандов на лабораторный итамм микобактерий туберкулеза $H_{37} R v$.

Ключевые слова: Основания Шиффа, 2,6-диформилфенол, конденсация, туберкулостатическая активность, комплексы 3d металлов. 


\section{Introduction}

Directed synthesis of polydentate organic compounds with various donor centers followed by metal complexes formation, their structures' definition and evaluation of regioselective coordination factors play an important role in design of artificial models of biologically important objects ${ }^{[1,2]}$ and searching for compounds with required physicochemical and applied properties, ${ }^{[3-5]}$ e.g. magnetic, ${ }^{[6,7]}$ catalytic, ${ }^{[8-10]}$ medicobiological, ${ }^{[11]}$ etc.

Previously we have reported on macroacyclic polydentate ligands via diethyl-2-[(2-aminophenyl)-aminomethylidene $]$ malonate or ethyl-2-[(2-aminophenyl)aminomethylidene]-3-oxo-3-(polyfluoro)alkylpropionates with thiophene-2,5-dicarboxaldehyde. ${ }^{[12,13]}$ It was shown the structure of their coordination centers depends on the symmetry of 1,3-dicarbonyl fragment. These compounds were expected to form complexes with $3 \mathrm{~d}$ metal ions; however our attempts to isolate stable chelates were unsuccessful because of sulfur atom in thiophene cycle seems to have the low donor ability for the formation of strong donor-acceptor bond with metal ion. ${ }^{[14]}$

Unlike thiophene-2,5-dicarboxaldehyde 2,6-diformylphenol have a hydroxy group that can provide the covalent bonding with metal ions. It is worth noting that 2,6-diformylphenol and its derivatives are widely used in the design of polydentate ligands which can form polynuclear complex systems having magnetic interaction between the metal centers. Due to the study of stereochemical, electronic, magnetic, catalytic, spectroscopic and biological properties one can suggest for them some important applications. ${ }^{[15-18]}$

In this paper we describe the synthesis, coordination properties and tuberculostatic activity of new macroacyclic Schiff base ligands based on 2,6-diformylphenol 1 and ethyl2-[(2-aminophenyl)aminomethylidene]-1,3-dicarbonyl compounds 2a-d.

\section{Results and Discussion}

It was found the reaction of dialdehyde 1 with amines 2a-d in ethanol at room temperature proceeds regioselectively and gives [1+2] condensation products diazomethines 3a-d in good yields (Scheme 1). Structures of 3a-d were characterized by IR, ${ }^{1} \mathrm{H},{ }^{19} \mathrm{~F}$ NMR spectroscopy and elemental analysis.

An important point is that compounds 3a-d have labile hydrogen atom and therefore they can be involved in keto-enol and amine-imine tautomerism. The imino-enone, imino-enol, and/or amino-enone tautomers are possible for their structure. Furthermore, amino-enone tautomers of 3-oxoesters derivatives $\mathbf{3 c}, \mathbf{d}$ can exhibit $Z, E$-isomerism because of different position of non-equivalent substituents relative to $\mathrm{C}=\mathrm{C}$ bond.

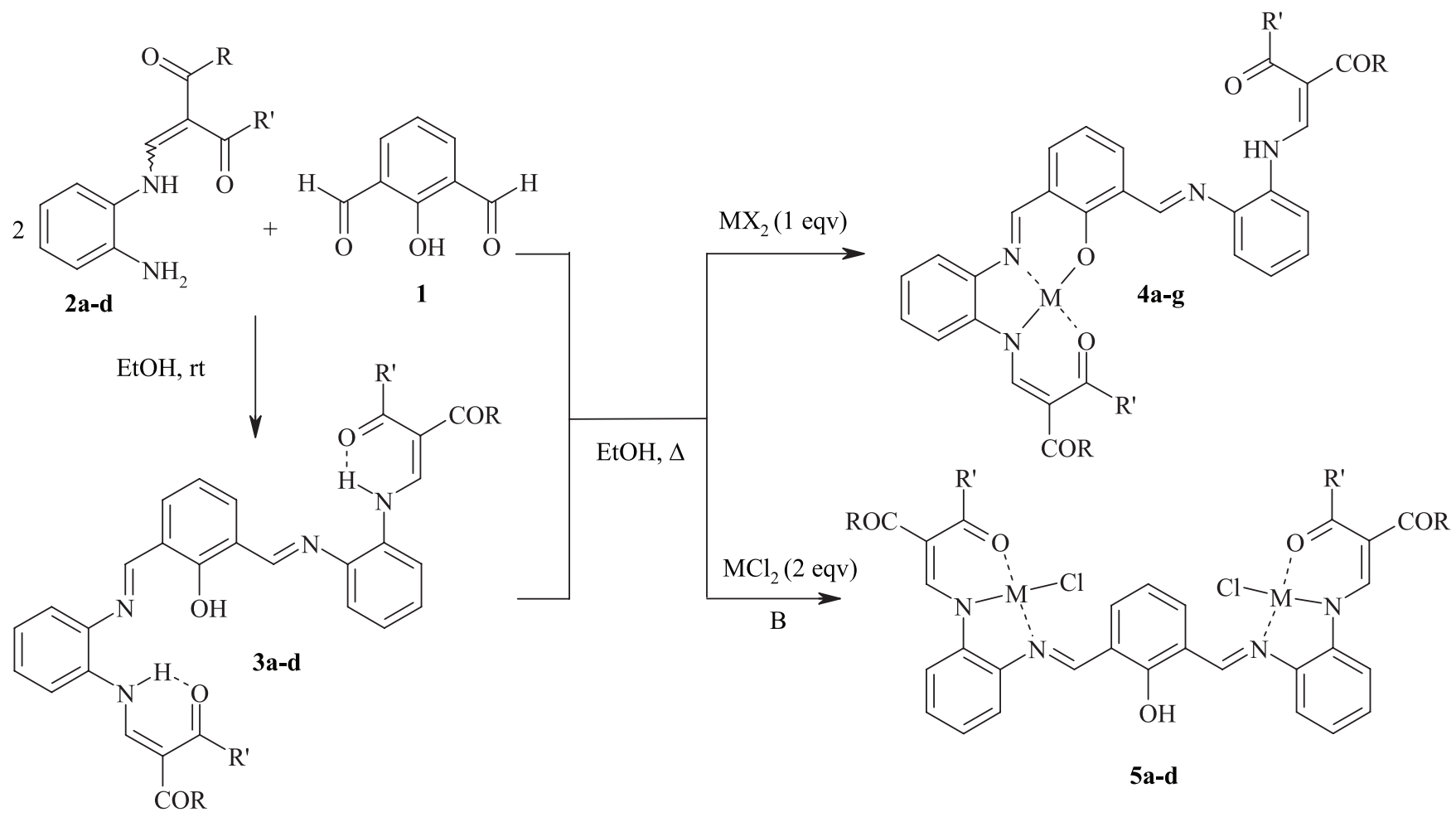

2, 3: $\mathrm{R}=\mathrm{R}^{\prime}=\mathrm{OEt}(\mathbf{a}) ; \mathrm{R}=\mathrm{R}^{\prime}=\mathrm{Me}(\mathbf{b}) ; \mathrm{R}=\mathrm{OEt}: \mathrm{R}^{\prime}=\mathrm{Me}(\mathbf{c}), \mathrm{CF}_{3}(\mathbf{d})$.

4: $\mathrm{R}=\mathrm{R}^{\prime}=\mathrm{OEt}: \mathrm{M}=\mathrm{Ni}(\mathbf{a}), \mathrm{Cu}(\mathbf{b}) ; \mathrm{R}=\mathrm{R}^{\prime}=\mathrm{Me}: \mathrm{M}=\mathrm{Ni}(\mathbf{c}) ; \mathrm{R}=\mathrm{OEt}, \mathrm{R}^{\prime}=\mathrm{Me}: \mathrm{M}=\mathrm{Ni}(\mathbf{d}), \mathrm{Cu}(\mathbf{e})$;

$\mathrm{R}=\mathrm{OEt}, \mathrm{R}^{\prime}=\mathrm{CF}_{3}: \mathrm{M}=\mathrm{Ni}(\mathbf{f}), \mathrm{Cu}(\mathrm{g})$.

5: $\mathrm{R}=\mathrm{R}^{\prime}=\mathrm{Me}, \mathrm{M}=\mathrm{Ni}(\mathbf{a}) ; \mathrm{R}=\mathrm{OEt}: \mathrm{R}^{\prime}=\mathrm{Me}, \mathrm{M}=\mathrm{Ni}(\mathbf{b}), \mathrm{Cu}(\mathbf{c}) ; \mathrm{R}=\mathrm{OEt}: \mathrm{R}^{\prime}=\mathrm{CF}_{3}, \mathrm{M}=\mathrm{Ni}(\mathbf{d})$.

$\mathrm{B}=\mathrm{Py}, \mathrm{DBU} ; \mathrm{X}=\mathrm{Cl}, \mathrm{OAc}$.

Scheme 1. 
Table 1. ${ }^{1} \mathrm{H}$ NMR spectral data $(\delta, \mathrm{ppm})$ of compounds $\mathbf{3 c}, \mathbf{d}$ in $\mathrm{CDCl}_{3}$.

\begin{tabular}{cccccccc}
\hline Compound & $\mathrm{R}$ & $\mathrm{R}^{\prime}$ & Isomer & $\begin{array}{c}\text { Methylene } \\
(=\mathrm{CH}-)\end{array}$ & $\begin{array}{c}\text { Azomethine } \\
(-\mathrm{HC}=\mathrm{N}-)\end{array}$ & $\begin{array}{c}\text { Amine } \\
(-\mathrm{NH})\end{array}$ & $\begin{array}{c}\text { Content, } \\
\%\end{array}$ \\
\hline \multirow{2}{*}{ 3c } & $\mathrm{Me}$ & & $\mathrm{EE}$ & 8.59 & 9.00 & 13.19 & 85 \\
& \multirow{2}{*}{ 3d } & $\mathrm{OEt}$ & $\mathrm{ZZ}$ & 8.58 & 8.89 & 12.59 & 15 \\
& $\mathrm{CF}_{3}$ & & $\mathrm{EE}$ & 8.71 & & 12.77 & 80 \\
\end{tabular}

A comparative analysis of IR spectra of azomethines 3a,b with symmetrical 1,3-dicarbonyl fragments revealed no substantial differences between them. Thus, their IR spectra have two high-frequency absorption bands corresponding to vibrations of ester (-CO $\mathrm{CO}_{2} \mathrm{Et}$ for 3a) or keto-groups (-COMe for $3 \mathbf{b})$ of two types: free carbonyl group (1709-1655 $\left.\mathrm{cm}^{-1}\right)$ and carbonyl group involved in the formation of intramolecular hydrogen bond (IMHB) (1690-1619 $\left.\mathrm{cm}^{-1}\right)$ with the $\mathrm{NH}$-group. The absorption bands of $\mathrm{NH}$-groups are observed at $3208-3069 \mathrm{~cm}^{-1}$. Based on this analyze one can conclude the existence of compounds $\mathbf{3 a}, \mathbf{b}$ as bis(amino-enone) tautomer in solid state. ${ }^{1} \mathrm{H}$ NMR spectra of $\mathbf{3 a}, \mathbf{b}$ in $\mathrm{CDCl}_{3}$ have one set of signals corresponds to bis(amino-enone) tautomer that confirmed the molecule symmetry preservation under dissolution.

The IR spectra of compounds $\mathbf{3 c}$, d, having 3-oxoester fragment, are characterized by absorption bands of free ethoxycarbonyl groups (1700-1697 $\left.\mathrm{cm}^{-1}\right)$ and (fluoro)acyl carbonyl groups $\left(1689-1633 \mathrm{~cm}^{-1}\right)$ participated in IMHB with NH-groups (3176-3154 $\left.\mathrm{cm}^{-1}\right)$. In this case absorption bands are either doublet or broadened. Based on the IR spectra analogy we suggested for compounds $\mathbf{3 c}, \mathbf{d} E, E-$ isomeric structure in which bis(amino-enone) fragments stabilized with IMHB are in trans-position relative to aromatic spacer similarly to described earlier ${ }^{[13]}$ thiophene derivatives.

According to the ${ }^{1} \mathrm{H}$ and ${ }^{19} \mathrm{~F}$ NMR spectral data azomethines $\mathbf{3 c}, \mathbf{d}$ in $\mathrm{CDCl}_{3}$ solutions exist as mixtures of $E, E$ and $Z, Z$-isomers and $E, E$-isomer is prevalent (Table 1$)$. The $E, E$ - and $Z, Z$-isomeric forms in the ${ }^{1} \mathrm{H}$ and ${ }^{19} \mathrm{~F}$ NMR spectra were attributed in accordance with our previous work ${ }^{[19]}$ in which $\mathrm{CH}$ - and $\mathrm{NH}$-protons of $E E$-isomer are observed at lower field compared to that of $Z, Z$-isomer.

There are two $\left(\mathrm{N}_{2} \mathrm{O}_{2}-\right.$ and $\left.\mathrm{N}_{2} \mathrm{O}-\right)$ coordination centers capable of complex formation in the structure of compounds 3a-d. Their treatment with nickel(II) and copper(II) salts in equimolar ratio was shown to give mononuclear complexes 4a-g (yields 89-93\%). We were also succeeded in template synthesis of $\mathbf{4 a - g}$ from dialdehyde $\mathbf{1}$ and amines $\mathbf{2 a - d}$ with $3 \mathrm{~d}$ metal ions (yields 80-95\%). In both cases tetradentate $\mathrm{N}_{2} \mathrm{O}_{2}$ center participated in the complex formation.

Elemental analyses data of complexes $\mathbf{4 a - g}$ correspond to $\mathrm{M}[\mathrm{L}-\mathrm{H}]$ structure $(\mathrm{M}=$ metal, $\mathrm{L}=$ ligand). IR spectra of 4a-g contain both high-frequency absorption bands (1727$1690 \mathrm{~cm}^{-1}$ ) corresponding to the vibrations of free carbonyl groups $\left(\mathrm{CO}_{2} \mathrm{Et}\right.$ and $\left.\mathrm{R}^{(\mathrm{F})} \mathrm{C}=\mathrm{O}\right)$ and absorption bands of carbonyl groups which participate in the coordination with metal ions. The latter are characterized with low-frequency shift (1665-1615 $\left.\mathrm{cm}^{-1}\right)$. Absorption intensity decreasing of $\mathrm{NH}-$ and $\mathrm{OH}$-groups in the field of stretching vibrations is also observed (3206-3125 $\left.\mathrm{cm}^{-1}\right)$.
${ }^{1} \mathrm{H}$ NMR spectra of nickel(II) complexes 4a,c were suitable for the structure determination in solution. The absence of OH-group low field singlet and the presence of only one NH-group doublet indicate their involvement in covalent bonding with metal. Probably owing to the nickel(II) ion coordination only on one $\mathrm{N}_{2} \mathrm{O}_{2}$-center protons of symmetrical 1,3-dicarbonyl groups (-OEt for 4a and -Me for 4c) as well as protons of two $\mathrm{H}-\mathrm{C}=\mathrm{N}$ - and two $=\mathrm{CH}$ - groups become not equal (Figure 1). Thereby in ${ }^{1} \mathrm{H}$ NMR spectra of 4a,c there are three different sets of signals corresponding to protons of ethyl and methyl groups respectively. ${ }^{1} \mathrm{H}$ NMR spectrum of complex $\mathbf{4 a}$ in $\mathrm{CDCl}_{3}$ solution contains signals of $\mathrm{H}-\mathrm{C}=\mathrm{N}$ - and $=\mathrm{CH}$-groups of chelate moiety as singlets with different chemical shifts while $=\mathrm{CH}$-group of free $\mathrm{N}_{2} \mathrm{O}$ site appears as doublet due to the spin-spin coupling with proton of NH-group.<smiles>[R]O[M]C(C)(C)CC</smiles>

Figure 1. Non-equal protons in $\mathbf{4 a , c .}$

${ }^{1} \mathrm{H}$ NMR spectra of complexes $\mathbf{4 d}$,f $\mathbf{f}$ were uninformative because of strong signals broadening.

According to single-crystal X-Ray diffraction, nickel(II) atom in $\mathbf{4 d}$ has slightly distorted square-planar coordination with two $(\mathrm{N}(3)$ and $\mathrm{N}(4))$ nitrogen atoms of phenylenediamine fragment and two $(\mathrm{O}(3)$ and $\mathrm{O}(4))$ oxygen atoms of acyl and hydroxy groups belong to 1,3-dicarbonyl fragment and dialdehyde respectively (Figure 2 ). The distortion is caused by the difference between the lengths of a square N(3)-N(4)$\mathrm{O}(3)-\mathrm{O}(4)$ sides (maximum difference between $\mathrm{N}(3)-\mathrm{O}(4)$ and $\mathrm{O}(3)-\mathrm{O}(4)$ sides is $0.233 \AA$ ).

$\mathrm{N}_{2} \mathrm{O}$-center not participating in complex formation contains an intramolecular hydrogen bond (IMHB) $\mathrm{N}(2)$ $\mathrm{H}(2) \cdots \mathrm{O}(7)$. This IMHB is characterized by the following parameters: intramolecular distance $\mathrm{O}(7) \cdots \mathrm{H}(2)$ is $1.89(5)$ 


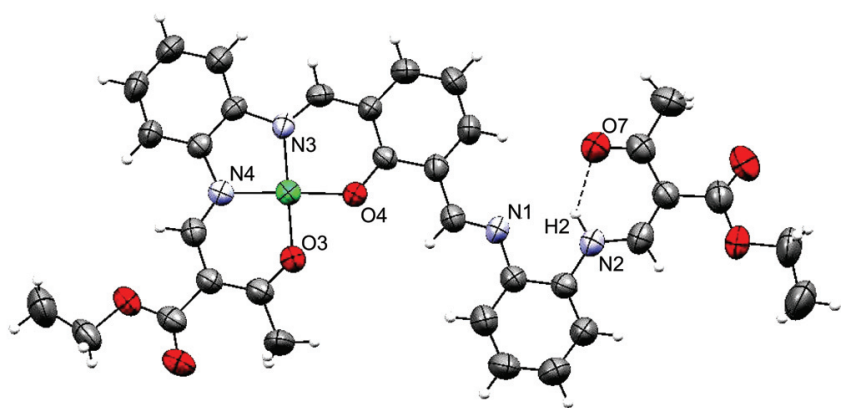

Figure 2. X-Ray structure of $\mathbf{4 d}$ (thermal ellipsoids at $50 \%$ probability level, ORTEP drawing).

$\AA, \mathrm{N}(2)-\mathrm{H}(2)$ is $0.92(3) \AA, \mathrm{N}(2) \cdots \mathrm{O}(7)$ is 2.61(8) $\AA$, angles $\mathrm{N}(2)-\mathrm{H}(2) \cdots \mathrm{O}(7)$ and $\mathrm{C}(10)-\mathrm{O}(7) \cdots \mathrm{H}(2)$ are $133.5(0)^{\circ}$ and $105.0(7)^{\circ}$ respectively.

The molecule of $4 \mathbf{d}$ has an approximately planar conformation; bonds of metal cycle are coplanar with adjacent aryl moieties. The deviation of atoms Ni-N(3)$\mathrm{N}(4)-\mathrm{O}(3)-\mathrm{O}(4)$, which form chelate center of the molecule, from its mean plane is not more than $0.10(5) \AA$.

Three conjugated metal cycles (two six- and one five-membered) are formed in the molecule as a result of tetradentate coordination. Electron density of six-membered metal cycles is strongly delocalized that leads to the equalization of $\mathrm{Ni}-\mathrm{X}, \mathrm{C}-\mathrm{X}$ and $\mathrm{C}-\mathrm{C}$ bond lengths $(\mathrm{X}=\mathrm{N}$, O) of the metal cycle.
Molecular packing of $\mathbf{4 d}$ is formed by translational molecules stacks with the interplanar distance 3.43(1) $\AA$ (Figure 3). The cavities between the stacks are occupied by pyridine molecules. Stacks are packed in parallel layers owing to $\pi-\pi$ stacking of phenyl rings of adjacent molecules. ${ }^{[20]}$

Reaction of ligand 3d with two equivalents of nickel(II) chloride and pyridine resulted in binuclear nickel complex $\mathbf{5 d}$. The main requirement providing complex formation on two $\mathrm{N}_{2} \mathrm{O}$-centers was the use of pyridine as a base in equimolar quantity that facilitates the deprotonation of $\mathrm{NH}$-groups. One-pot synthesis of binuclear complexes 5a-c from dialdehyde 1 and ethyl-2-[(2-aminophenyl)aminomethylidene]1,3-dicarbonyl compounds $\mathbf{2 b}, \mathbf{c}$ on the nickel(II)/copper(II) ions template was also successful and in this case DBU was used as a base. Advantage of one-pot method is absence of additional stages of ligand isolation and purification and as a result a higher yield of metal complex.

Spectral data of 5a-d demonstrated both coordination centers involved in complex formation. Elemental composition of 5a-d corresponds to $\mathrm{M}_{2}[\mathrm{~L}-\mathrm{OH}] \mathrm{Cl}_{2}$ structure $(\mathrm{M}=$ metal, $\mathrm{L}=$ ligand). IR spectra have high-frequency absorption bands at $1727-1668 \mathrm{~cm}^{-1}$ corresponding to the vibrations of carbonyl groups in ester and (fluoro)acyl moieties. A comparison of 4a-f and 5a-d IR spectra reveal their differences: in complexes 5a-d spectra there are no high-frequency absorption bands at $3100-3300 \mathrm{~cm}^{-1}$ corresponds to the stretching vibrations of $\mathrm{NH}$-groups that denotes the participation of both $\mathrm{N}_{2} \mathrm{O}$-coordination centers in complexation.

The structure of binuclear nickel(II) metal complexes $\mathbf{5 a}, \mathbf{b}, \mathbf{d}$ in solution was defined by means of ${ }^{1} \mathrm{H},{ }^{19} \mathrm{~F}$ NMR

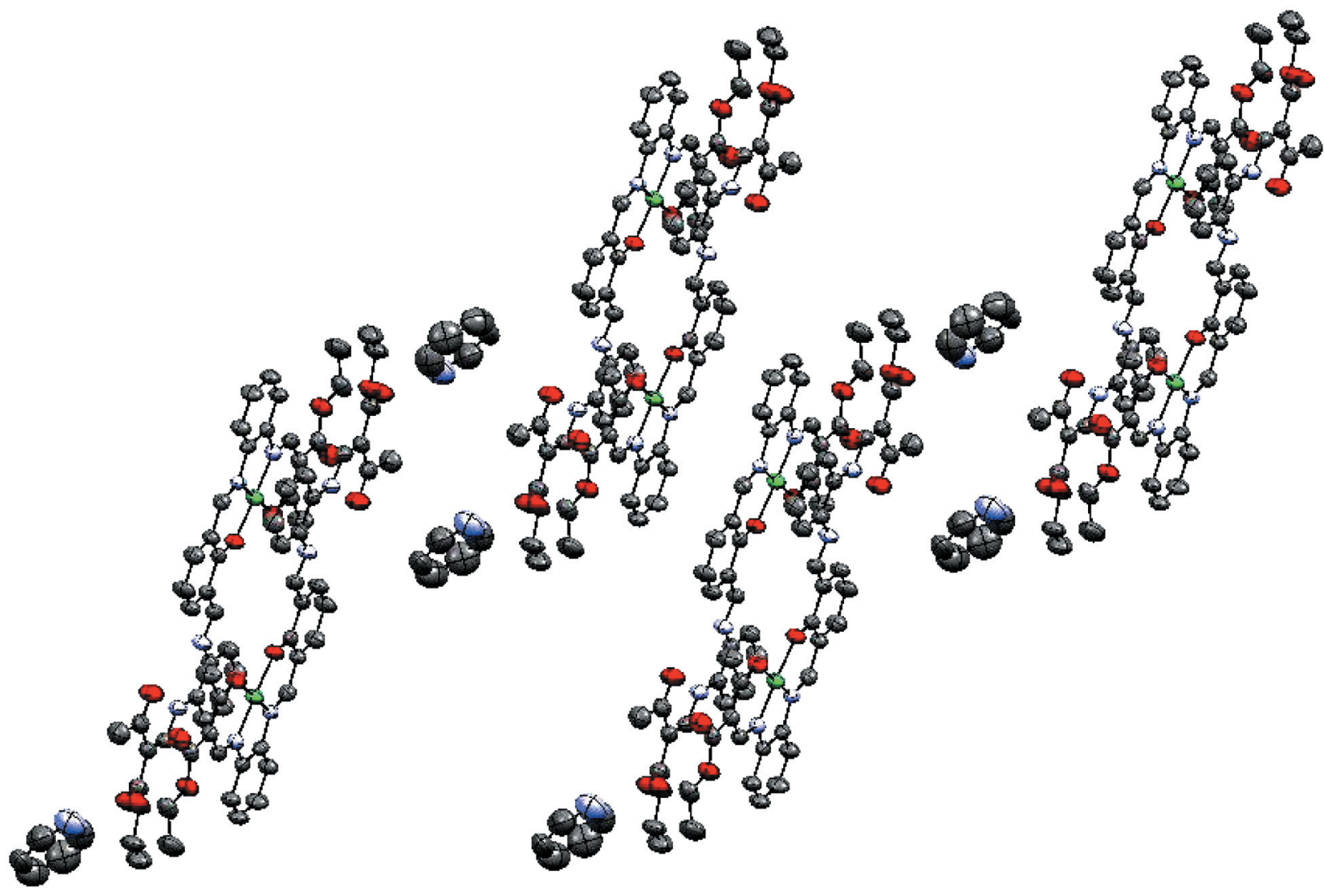

Figure 3. Molecular packing of nickel(II) complex $4 \mathbf{d}$ (along the $b$ axis). 
spectroscopy. In consequence of nickel(II) coordination on two $\mathrm{N}_{2} \mathrm{O}$-centers protons of symmetrical 1,3-dicarbonyl groups as well as $\mathrm{H}-\mathrm{C}=\mathrm{N}$ - and $=\mathrm{CH}$-groups become equal and this fact is confirmed by the presence of one set of signals in spectra. It should be noted the covalent bond with metal ions in binuclear complexes 5 is realized via two $\mathrm{NH}$-groups of the ligand 3 and counterions of corresponding salts $\left(\mathrm{Cl}^{-}\right)$. In this case oxygen atoms of (fluoro)acyl $\mathrm{C}=\mathrm{O}$ groups participate in coordination bonding. ${ }^{1} \mathrm{H}$ NMR spectra of nickel(II) complexes 5a,b,d have low-field singlets correspond to free hydroxy-group of 2,6-diformylphenol $1\left(\delta_{\mathrm{OH}} \sim 10.3-10.5\right.$ ppm). Complexation occurs on ketoendiimine fragment to form a symmetrical structure. The symmetry of functional groups' signals in ${ }^{1} \mathrm{H},{ }^{19} \mathrm{~F}$ NMR spectra points out at the equivalence of coordination centers.

To our best knowledge one of the antituberculous aspects of isoniazid (isonicotinic acid hydrazide) action is the ability to form metal complexes which alters the normal microorganisms' activity and prevents mycobacteria multiplication. ${ }^{[21]}$ Within this context and taking into account the complexing properties of diazomethines $\mathbf{3}$ we were estimated tuberculostatic activity of $\mathbf{3 c}, \mathbf{d}$ in vitro by their effect on the growth inhibition of Mycobacterium tuberculosis $\mathrm{H}_{37} \mathrm{Rv}$. Isoniazid was used as a reference drug with minimum inhibition concentration (MIC) $0.15 \mu \mathrm{g} / \mathrm{ml}$. The MIC was defined as the lowest concentration of drug required for M. tuberculosis $\mathrm{H}_{37} \mathrm{Rv}$ growth inhibition. Both non-fluorinated diazomethine $\mathbf{3} \mathbf{c}$ and fluorinated one $\mathbf{3 d}$ demonstrated a moderate effect against $M$. tuberculosis $\mathrm{H}_{37} \mathrm{Rv}$ with MIC $6.2 \mu \mathrm{g} / \mathrm{ml}$.

\section{Experimental}

\section{Equipment}

Melting points were measured in open capillaries with a Stuart SMP3 apparatus for melting temperature determination. The IR diffuse reflectance spectra were recorded on a Perkin Elmer Spectrum One Fourier FT-IR instrument in the interval 400-4000 $\mathrm{cm}^{-1}$ in the solid state as powders on a stick using a diffuse reflectance attachment (DRA). The ${ }^{1} \mathrm{H}(400 \mathrm{MHz})$ and ${ }^{19} \mathrm{~F}(376 \mathrm{MHz}) \mathrm{NMR}$ spectra were recorded on a Bruker DRX-400 spectrometer with $\left(\mathrm{CH}_{3}\right)_{4} \mathrm{Si}$ and $\mathrm{C}_{6} \mathrm{~F}_{6}$ as internal standarts, respectively. Elemental analyses were performed on a Perkin Elmer PE 2400 series II elemental analyzer.

\section{Tuberculostatic Activity Determination Method}

Determination of $\mathbf{3 c}, \mathbf{d}$ tuberculostatic activity was carried out with the use of solid culture medium Novaya by vertical diffusion method. For inoculation the laboratory strain $\mathrm{H}_{37} \mathrm{Rv}$ was prepared. The culture of laboratory strain was weighed on a torsion balance and sample $(10 \mathrm{mg})$ was placed into porcelain mortar and triturated thoroughly; then the culture suspension was prepared by bacterial turbidity standard (100 million microbial bodies $/ \mathrm{ml})$. The suspension obtained $(2 \mathrm{ml})$ was inoculated into tubes containing culture medium and a test compound $(5 \mathrm{ml})$ of appropriate dilution. Prepared by serial dilution the following concentrations were used: $100,50,12.5,6.2,3.5,1.5,0.7,0.3,0.15$ $\mu \mathrm{g} / \mathrm{ml}$. The tube was incubated in calorstat for $7-10$ days at $37^{\circ} \mathrm{C}$. Study of test substances effect on the growth of Mycobacterium tuberculosis $\mathrm{H}_{37} \mathrm{Rv}$ was performed in three parallel tubes at each concentration.

\section{Materials}

Reactions were monitored by thin layer chromatography (TLC) with $0.20 \mathrm{~mm}$ Alugram Sil G/UV ${ }_{254}$ pre-coated silica gel plates (60 F254). The column chromatography was carried out on Merck silica gel $60(0.063-0.200 \mathrm{~mm})$. Unless otherwise mentioned, all commercially available compounds and solvents were used as received (2,6-diformylphenol 1 ( $>98.0 \%$ ) was purchased from Tokio Chemical Industry Co., Ltd., pyridine (ACS $99 \%$ ) from Alfa Aesar, 1,8-diazabicyclo[5.4.0] undec-7-ene (DBU) (98\%) from Acros Organics). Ethanol was purified and dried according to standard procedures. ${ }^{[22]}$ Diethyl 2-[(2-aminophenyl)aminomethylidene $]-$ malonate 2a, ${ }^{[12]} 3-[(2$-aminophenyl) aminomethylidene]pentane2,4-dione $\mathbf{2} \mathbf{b}^{[23]}$ and ethyl 2-[(2-aminophenyl)aminomethylidene]3-oxo-3-(polyfluoro)alkylpropionates $\mathbf{2 c}, \mathbf{d}^{[24,25]}$ were synthesized according to previously reported procedures.

\section{X-Ray Crystallography}

Crystallographic data for $4 d: \mathrm{C}_{34} \mathrm{H}_{32} \mathrm{~N}_{4} \mathrm{NiO}_{7} \cdot \mathrm{C}_{5} \mathrm{H}_{5} \mathrm{~N}, \mathrm{M}=$ 746.45, triclinic, space group P-1, $a=11.6344(5), b=11.7919(11)$ and $c=14.4670(14) \AA, \quad \alpha=74.476(9)^{\circ}, \quad \beta=68.460(8)^{\circ}, \quad \gamma=$ $76.303(8)^{\circ}, V=1757.4(2) \AA^{3}, Z=2, d_{\text {calc }}=1.411 \mathrm{~g} \cdot \mathrm{cm}^{-3}, \mu(\mathrm{MoK} \alpha)$ $=0.611 \mathrm{~cm}^{-1}, F(000)=780$. A total number of 12747 reflections were measured on an Xcalibur 3 diffractometer at 295(2) $\mathrm{K}[(\omega / 2 \theta-$ scanning technique, MoK $\alpha$ radiation $(\lambda=0.71073 \AA)$, graphite monochromator, CCD detector], 7084 independent reflections $\left(R_{\text {int }}=0.0394\right), 3602$ reflections with $F_{\mathrm{o}}>4 \sigma\left(F_{\mathrm{o}}\right)$. The structure was solved by direct methods and refined by the least-squares method with the use of SHELXL-97 ${ }^{[26]}$ program package to $R_{1}=0.0440$, $w R_{2}=0.0653$ and GOOF $=1.005$ [based on reflections with $I>$ $2 \sigma(I)]$.

CCDC 961402 contains the supplementary crystallographic data for this paper. These data can be obtained free of charge from The Cambridge Crystallographic Data Centre via www.ccdc.cam. ac.uk/data_request/cif.

\section{Synthesis}

Diazomethines 3a-d (general procedure). To a solution of 2,6diformylphenol 1 (0.75 g, $5 \mathrm{mmol})$ in anhydrous EtOH $(40 \mathrm{ml})$ the corresponding ester $2(10 \mathrm{mmol})$ was added. After stirring for $4 \mathrm{~h}$ the precipitate formed was separated by filtration, crystallized from $\mathrm{MeCN}$ and dried to give products 3a-d as bright yellow powders.

Tetraethyl 2,2'-[1,3-(2-hydroxybenzylidene)-bis(aminomethylidene-2-iminophenylene)] dimalonate (3a). Prepared from ester 2a (2.78 g). Yield $3.19 \mathrm{~g}(95 \%)$, mp $152-153^{\circ} \mathrm{C}$. Found: $\mathrm{C}$ 64.34, H 5.67, N $8.40 \% . \mathrm{C}_{36} \mathrm{H}_{38} \mathrm{~N}_{4} \mathrm{O}_{9}$ requires $\mathrm{C} 64.47, \mathrm{H} 5.71$, $\mathrm{N}, 8.35$. IR $v \mathrm{~cm}^{-1}$ : 3208, $3195(\mathrm{~N}-\mathrm{H}, \mathrm{O}-\mathrm{H}) ; 3065,2978(\mathrm{C}-\mathrm{H})$; 1709, $1690(\mathrm{C}=\mathrm{O}) ; 1647(\mathrm{C}=\mathrm{N}) ; 1614,1566(\mathrm{C}=\mathrm{C}, \mathrm{N}-\mathrm{H}) .{ }^{1} \mathrm{H}$ NMR $\left(\mathrm{CDCl}_{3}\right) \delta$ ppm: $1.33,1.36$ (two t, $J=7.1 \mathrm{~Hz}$, both $6 \mathrm{H}, 4 \mathrm{OCH}_{2} \mathrm{CH}_{3}$ ), 4.26, 4.34 (two q, $J=7.1 \mathrm{~Hz}$, both $4 \mathrm{H}, 4 \mathrm{OCH}_{2} \mathrm{CH}_{3}$ ), 7.10-7.36 (m, $10 \mathrm{H}, \mathrm{Ar}), 8.17$ (m, 1H, Ar), 8.60 (d, $J=13.9 \mathrm{~Hz}, 2 \mathrm{H}, 2=\mathrm{CH}), 9.00$ (s, 2H, $2 \mathrm{H}-\mathrm{C}=\mathrm{N}), 11.67$ (br d, $J=13.9 \mathrm{~Hz}, 2 \mathrm{H}, 2 \mathrm{NH}$ )

3,3'-[1,3-(2-Hydroxybenzylidene)-bis(aminomethylidene-2iminophenylene)]-bis(pentane-2,4-dione) (3b). Prepared from ester 2b $(2.18 \mathrm{~g})$. Yield $2.48 \mathrm{~g}(90 \%)$, mp $260-261^{\circ} \mathrm{C}$. Found: C 69.70 , H 5.20, N $10.03 \%$. $\mathrm{C}_{32} \mathrm{H}_{30} \mathrm{~N}_{4} \mathrm{O}_{5}$ requires C 69.80, H 5.49, N 10.18 . IR $v \mathrm{~cm}^{-1}$ : $3069(\mathrm{~N}-\mathrm{H}) ; 2923,2852(\mathrm{C}-\mathrm{H}) ; 1655,1619(\mathrm{C}=\mathrm{O}) ; 1597$ $(\mathrm{C}=\mathrm{N}) ; 1580,1560(\mathrm{C}=\mathrm{C}, \mathrm{N}-\mathrm{H}) .{ }^{1} \mathrm{H}$ NMR $\left(\mathrm{CDCl}_{3}\right) \delta \mathrm{ppm}: 2.40$, 2.58 (two s, both 6H, $4 \mathrm{Me}$ ), 6.82-6.89, 7.08-7.37, 7.88-7.90, 8.138.16 (all m, 10H, Ar), 8.25 (br s, $1 \mathrm{H}, \mathrm{Ar}), 8.33$ (d, $J=12.9 \mathrm{~Hz}, 2 \mathrm{H}$, $2=\mathrm{CH}), 9.01(\mathrm{~s}, 2 \mathrm{H}, 2 \mathrm{H}-\mathrm{C}=\mathrm{N}), 12.88(\mathrm{~s}, 1 \mathrm{H}, \mathrm{OH}), 13.18(\mathrm{br} \mathrm{d}, J=$ $12.9 \mathrm{~Hz}, 2 \mathrm{H}, 2 \mathrm{NH})$.

Diethyl 2,2'-[1,3-(2-hydroxybenzylidene)-bis(aminomethylidene-2-iminophenylene)] bis(3-oxobutanoate) (3c). Prepared from ester $2 \mathrm{c}(2.48 \mathrm{~g})$. Yield $2.99 \mathrm{~g}(98 \%), \mathrm{mp} 204-205^{\circ} \mathrm{C}$. Found: $\mathrm{C}$ 66.80, H 5.61, N $9.18 \% . \mathrm{C}_{34} \mathrm{H}_{34} \mathrm{~N}_{4} \mathrm{O}_{7}$ requires $\mathrm{C} 66.87, \mathrm{H} 5.61, \mathrm{~N}$ 
9.17. IR $v \mathrm{~cm}^{-1}: 3210,3185(\mathrm{~N}-\mathrm{H}, \mathrm{O}-\mathrm{H}) ; 2983(\mathrm{C}-\mathrm{H}) ; 1700,1689$ $(\mathrm{C}=\mathrm{O}) ; 1619(\mathrm{C}=\mathrm{N}) ; 1597,1586,1560(\mathrm{C}=\mathrm{C}, \mathrm{N}-\mathrm{H}) .{ }^{1} \mathrm{H}$ NMR $\left(\mathrm{CDCl}_{3}\right) \delta$ ppm: 7.15-7.25, 7.30-7.41 (two m, 10H, Ar), 8.20 (br s, $1 \mathrm{H}, \mathrm{Ar}) ; E, E(85 \%): 1.35\left(\mathrm{t}, J=7.1 \mathrm{~Hz}, 6 \mathrm{H}, 2 \mathrm{OCH}_{2} \mathrm{CH}_{3}\right), 2.57(\mathrm{~s}$, $6 \mathrm{H}, 2 \mathrm{Me}), 4.29$ (q, $\left.J=7.1 \mathrm{~Hz}, 4 \mathrm{H}, 2 \mathrm{OCH}_{2} \mathrm{CH}_{3}\right), 8.59$ (d, $J=13.4$ $\mathrm{Hz}, 2 \mathrm{H}, 2=\mathrm{CH}), 9.00($ br s, $2 \mathrm{H}, 2 \mathrm{H}-\mathrm{C}=\mathrm{N}), 13.19$ (br d, $J=13.4$ $\mathrm{Hz}, 2 \mathrm{H}, 2 \mathrm{NH}) ; Z, Z(15 \%): 1.30\left(\mathrm{t}, J=7.1 \mathrm{~Hz}, 6 \mathrm{H}, 2 \mathrm{OCH}_{2} \mathrm{CH}_{3}\right)$, $2.51(\mathrm{~s}, 6 \mathrm{H}, 2 \mathrm{Me}), 4.41$ (q, $\left.J=7.1 \mathrm{~Hz}, 4 \mathrm{H}, 2 \mathrm{OCH}_{2} \mathrm{CH}_{3}\right), 8.58$ (d, $J=13.4 \mathrm{~Hz}, 2 \mathrm{H}, 2=\mathrm{CH}), 8.89$ (s, 2H, $2 \mathrm{H}-\mathrm{C}=\mathrm{N}), 12.59$ (br d, $J=$ $13.4 \mathrm{~Hz}, 2 \mathrm{H}, 2 \mathrm{NH})$

Diethyl 2,2'-[1,3-(2-hydroxybenzylidene)-bis(aminomethylidene-2-iminophenylene)]bis(3-oxo-4,4,4-trifluorobutanoate) (3d). Prepared from ester 2d (3.02 g). Yield 2.44 g (68 \%), mp 140-141 ${ }^{\circ} \mathrm{C}$. Found: C 56.72, H 3.88, F 15.80, N $7.86 \%$. $\mathrm{C}_{34} \mathrm{H}_{28} \mathrm{~F}_{6} \mathrm{~N}_{4} \mathrm{O}_{7}$ requires $\mathrm{C} 56.83, \mathrm{H} 3.93, \mathrm{~F} 15.86, \mathrm{~N} 7.80$. IR $v \mathrm{~cm}^{-1}: 3200,3176$ $(\mathrm{N}-\mathrm{H}, \mathrm{O}-\mathrm{H}) ; 3074,2986(\mathrm{C}-\mathrm{H}) ; 1697$ br $(\mathrm{C}=\mathrm{O}) ; 1633(\mathrm{C}=\mathrm{N}) ; 1603$, 1587, $1564(\mathrm{C}=\mathrm{C}, \mathrm{N}-\mathrm{H})$; 1276-1149 (C-F). ${ }^{1} \mathrm{H}$ NMR $\left(\mathrm{CDCl}_{3}\right) \delta$ ppm: 7.18-7.24, 7.30-7.41, 7.45-7.47 (all m, 10H, Ar), 8.22 (br s, $1 \mathrm{H}, \mathrm{Ar}), 9.02(\mathrm{~m}, 2 \mathrm{H}, 2 \mathrm{H}-\mathrm{C}=\mathrm{N}) ; E, E(80 \%): 1.34(\mathrm{t}, J=7.1 \mathrm{~Hz}$, $\left.6 \mathrm{H}, 2 \mathrm{OCH}_{2} \mathrm{CH}_{3}\right), 4.30$ (q, $\left.J=7.1 \mathrm{~Hz}, 4 \mathrm{H}, 2 \mathrm{OCH}_{2} \mathrm{CH}_{3}\right), 8.71$ (d, $J$ $=14.3 \mathrm{~Hz}, 2 \mathrm{H}, 2=\mathrm{CH}), 12.75(\mathrm{~s}, 1 \mathrm{H}, \mathrm{OH}), 12.77(\mathrm{br} \mathrm{d}, J=14.3 \mathrm{~Hz}$, $2 \mathrm{H}, 2 \mathrm{NH}) ; Z, Z(20 \%): 1.35$ (t, $\left.J=7.1 \mathrm{~Hz}, 6 \mathrm{H}, 2 \mathrm{OCH}_{2} \mathrm{CH}_{3}\right), 4.31$ (q, $\left.J=7.1 \mathrm{~Hz}, 4 \mathrm{H}, 2 \mathrm{OCH}_{2} \mathrm{CH}_{3}\right), 8.57(\mathrm{~d}, J=14.3 \mathrm{~Hz}, 2 \mathrm{H}, 2=\mathrm{CH})$, 12.08 (br d, $J=14.3 \mathrm{~Hz}, 2 \mathrm{H}, 2 \mathrm{NH}), 12.77$ (s, 1H, OH). ${ }^{19} \mathrm{~F}$ NMR $\left(\mathrm{CDCl}_{3}\right) \delta_{\mathrm{F}} \mathrm{ppm}: E, E(80 \%)$ : $89.12\left(\mathrm{~s}, 6 \mathrm{~F}, 2 \mathrm{CF}_{3}\right) ; Z, Z(20 \%)$ : $90.00\left(\mathrm{~s}, 6 \mathrm{~F}, 2 \mathrm{CF}_{3}\right)$.

Mononuclear complexes 4 (general procedure):

$A$. To a solution of ester $3(4 \mathrm{mmol})$ in refluxing ethanol (30 $\mathrm{ml})$ the appropriate metal salt $\left(\mathrm{Ni}(\mathrm{OAc})_{2} \cdot 4 \mathrm{H}_{2} \mathrm{O}\right.$ or $\mathrm{CuCl}_{2} \cdot 2 \mathrm{H}_{2} \mathrm{O}, 2$ mmol) was added and the reaction mixture was cooled to room temperature under stirring. The precipitate formed was separated by filtration and crystallized from EtOH.

$B$. To a solution of 2,6-diformylphenol $1(0.30 \mathrm{~g}, 2 \mathrm{mmol})$ in $\mathrm{EtOH}(20 \mathrm{ml})$ the appropriate metal salt $\left(\mathrm{Ni}(\mathrm{OAc})_{2} \cdot 4 \mathrm{H}_{2} \mathrm{O}\right.$ or $\left.\mathrm{CuCl}_{2} \cdot 2 \mathrm{H}_{2} \mathrm{O}, 2 \mathrm{mmol}\right)$ was added. Mixture was slightly heated under stirring until reactants dissolved followed by the dropwise addition of solution of ester 2 (4 mmol) in EtOH $(15 \mathrm{ml})$. The reaction mixture was stirred for $2 \mathrm{~h}$ at room temperature and the precipitation formed was filtered and crystallized from EtOH.

Mononuclear nickel(II) complex 4a. Yield 1.32 g (91\%) $(A), 1.24 \mathrm{~g}(85 \%)(B), \mathrm{mp} 234-235{ }^{\circ} \mathrm{C}$ (red powder). Found: $\mathrm{C}$ 59.34, H 4.60, N 7.30, Ni $8.10 \%$. $\mathrm{C}_{36} \mathrm{H}_{36} \mathrm{~N}_{4} \mathrm{NiO}_{9}$ requires C 59.44, $\mathrm{H}$ 4.99, N 7.70, Ni, 8.07. IR $v \mathrm{~cm}^{-1}: 3183$ (N-H); 3054, 2979 (C-H); 1711, 1676, $1665(\mathrm{C}=\mathrm{O}) ; 1648(\mathrm{C}=\mathrm{N}) ; 1599,1581,1532(\mathrm{C}=\mathrm{C}$, $\mathrm{N}-\mathrm{H}) .{ }^{1} \mathrm{H}$ NMR $\left(\mathrm{CDCl}_{3}\right) \delta$ ppm: $1.33,1.35,1.40$ (all t, $J=7.1$ $\mathrm{Hz}, 12 \mathrm{H}, 4 \mathrm{OCH}_{2} \mathrm{CH}_{3}$ ) $, 4.21,4.27,4.36$ (all q, $J=7.1 \mathrm{~Hz}, 8 \mathrm{H}, 4$ $\mathrm{OCH}_{2} \mathrm{CH}_{3}$ ), 6.68-6.76, 6.94-7.22, 7.28-7.38, 7.49-7.56 (all m, 9H, Ar), $7.85(\mathrm{dd}, J=7.4,1.4 \mathrm{~Hz}, 1 \mathrm{H}, \mathrm{Ar}), 7.98\left(\mathrm{~s}, 1 \mathrm{H}, \mathrm{H}^{2}-\mathrm{C}=\mathrm{N}\right), 8.29$ $\left(\mathrm{s}, 1 \mathrm{H},=\mathrm{CH}^{4}\right), 8.52(\mathrm{dd}, J=7.4,1.4 \mathrm{~Hz}, 1 \mathrm{H}, \mathrm{Ar}), 8.59(\mathrm{~d}, J=14.2$ $\left.\mathrm{Hz}, 2 \mathrm{H},=\mathrm{CH}^{1}\right), 9.05\left(\mathrm{~s}, 1 \mathrm{H}, \mathrm{H}^{3}-\mathrm{C}=\mathrm{N}\right), 11.97($ br d, $J=14.2 \mathrm{~Hz}$, $1 \mathrm{H}, \mathrm{NH})$.

Mononuclear copper(II) complex 4 b. Yield $1.36 \mathrm{~g}(93 \%)(A)$, $1.27 \mathrm{~g}(87 \%)(B), \mathrm{mp} 203-204{ }^{\circ} \mathrm{C}$ (dark brown powder). Found: $\mathrm{C}$ 57.51, $\mathrm{H} 4.60, \mathrm{~N} 7.15, \mathrm{Cu} 8.76 \% . \mathrm{C}_{36} \mathrm{H}_{36} \mathrm{CuN}_{4} \mathrm{O}_{9} \cdot \mathrm{H}_{2} \mathrm{O}$ requires $\mathrm{C}$ 57.63, H 5.11, N 7.47, $\mathrm{Cu}$ 8.47. IR $v \mathrm{~cm}^{-1}: 3206(\mathrm{~N}-\mathrm{H}) ; 3064,2977$ $(\mathrm{C}-\mathrm{H}) ; 1708,1658(\mathrm{C}=\mathrm{O}) ; 1605(\mathrm{C}=\mathrm{N}) ; 1582,1535(\mathrm{C}=\mathrm{C}, \mathrm{N}-\mathrm{H})$.

Mononuclear nickel(II) complex 4c. Yield $1.09 \mathrm{~g} \mathrm{(90 \% )} \mathrm{(A),}$

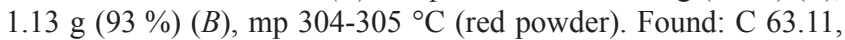
$\mathrm{H} 4.56, \mathrm{~N} 9.23$, Ni $9.60 \% . \mathrm{C}_{32} \mathrm{H}_{28} \mathrm{~N}_{4} \mathrm{NiO}_{5}$ requires $\mathrm{C} 63.29, \mathrm{H} 4.65$, N 9.23, Ni 9.66. IR $v \mathrm{~cm}^{-1}: 3159(\mathrm{~N}-\mathrm{H}) ; 3059,2994(\mathrm{C}-\mathrm{H}) ; 1640$, $1615(\mathrm{C}=\mathrm{O}) ; 1599(\mathrm{C}=\mathrm{N}) ; 1580,1561,1532(\mathrm{C}=\mathrm{C}, \mathrm{N}-\mathrm{H}) .{ }^{1} \mathrm{H}$ NMR $\left(\right.$ Py- $\left.d_{5}\right) \delta$ ppm: 2.55, 2.57, 1.69 (all s, 12H, $4 \mathrm{Me}$ ), 7.14, 7.17 (two br s, 4H, Ar), 7.36-7.39, 7.43, 7.51, 7.76-7.78, 7.85 (all m, 7H, Ar), 8.50-8.55 (m, 2H, $2 \mathrm{H}-\mathrm{C}=\mathrm{N}), 8.62(\mathrm{~d}, J=13.2 \mathrm{~Hz}, 2 \mathrm{H}, 2=\mathrm{CH})$, 13.50 (br d, $J=13.2 \mathrm{~Hz}, 1 \mathrm{H}, \mathrm{NH})$.

Mononuclear nickel(II) complex 4d. Yield 1.18 g (89\%) (A), $1.07 \mathrm{~g}(80 \%)(B), \mathrm{mp} 262-263{ }^{\circ} \mathrm{C}$ (red powder). Found: C 61.05, $\mathrm{H} 4.76, \mathrm{~N} 8.39$, Ni $9.03 \% . \mathrm{C}_{34} \mathrm{H}_{32} \mathrm{~N}_{4} \mathrm{NiO}_{7}$ requires $\mathrm{C} 61.19, \mathrm{H} 4.83$,
N 8.40, Ni 8.80. IR $v \mathrm{~cm}^{-1}: 3125(\mathrm{~N}-\mathrm{H}) ; 2981,2928(\mathrm{C}-\mathrm{H}) ; 1701 \mathrm{br}$ $(\mathrm{C}=\mathrm{O}) ; 1643(\mathrm{C}=\mathrm{N}) ; 1606,1535(\mathrm{C}=\mathrm{C}, \mathrm{N}-\mathrm{H})$.

Mononuclear copper(II) complex $4 \boldsymbol{e}$. Yield $1.22 \mathrm{~g}(91 \%)(A)$, $1.28 \mathrm{~g}(95 \%)(B), \mathrm{mp} 248-249^{\circ} \mathrm{C}$ (dark brown powder). Found: $\mathrm{C}$ 60.30, $\mathrm{H} 4.58, \mathrm{~N} 8.20, \mathrm{Cu} 9.51 \% . \mathrm{C}_{34} \mathrm{H}_{32} \mathrm{CuN}_{4} \mathrm{O}_{7}$ requires $\mathrm{C} 60.75$, $\mathrm{H}$ 4.80, N 8.34, Cu 9.45. IR v cm ${ }^{-1}: 3163(\mathrm{~N}-\mathrm{H}) ; 3062,2978(\mathrm{C}-\mathrm{H})$; 1700, $1689(\mathrm{C}=\mathrm{O}) ; 1632(\mathrm{C}=\mathrm{N}) ; 1602,1539(\mathrm{C}=\mathrm{C}, \mathrm{N}-\mathrm{H})$.

Mononuclear nickel(II) complex 4f. Yield $1.38 \mathrm{~g}(89 \%)(A)$, $1.41 \mathrm{~g}(91 \%)(B), \mathrm{mp} 253-254{ }^{\circ} \mathrm{C}$ (red powder). Found: C 52.77, $\mathrm{H} 3.19, \mathrm{~F} 14.39, \mathrm{~N} 7.38 \%$. $\mathrm{C}_{34} \mathrm{H}_{26} \mathrm{~F}_{6} \mathrm{~N}_{4} \mathrm{NiO}_{7}$ requires $\mathrm{C} 52.67, \mathrm{H}$ 3.38, F 14.70, N 7.23. IR $v \mathrm{~cm}^{-1}: 3175(\mathrm{~N}-\mathrm{H}) ; 2985(\mathrm{C}-\mathrm{H}) ; 1727$, $1704(\mathrm{C}=\mathrm{O}) ; 1639(\mathrm{C}=\mathrm{N})$; 1617, 1605, $1588(\mathrm{C}=\mathrm{C}, \mathrm{N}-\mathrm{H}) ; 1282$ $1156(\mathrm{C}-\mathrm{F})$

Mononuclear copper(II) complex $4 g$. Yield $1.36 \mathrm{~g}(87 \%)(A)$, $1.40 \mathrm{~g}(90 \%)(B), \mathrm{mp} 265-266{ }^{\circ} \mathrm{C}$ (dark brown powder). Found: C 52.66, H 3.45, F 14.51, N $7.54 \%$. $\mathrm{C}_{34} \mathrm{H}_{26} \mathrm{CuF}_{6} \mathrm{~N}_{4} \mathrm{O}_{7}$ requires $\mathrm{C}$ 52.35, H 3.36, F 14.61, N 7.18. IR $v \mathrm{~cm}^{-1}: 3182(\mathrm{~N}-\mathrm{H}) ; 3076,2982$ $(\mathrm{C}-\mathrm{H})$; 1726, $1704(\mathrm{C}=\mathrm{O}) ; 1640(\mathrm{C}=\mathrm{N}) ; 1607,1590,1538(\mathrm{C}=\mathrm{C}$, $\mathrm{N}-\mathrm{H})$.

Binuclear complexes $\mathbf{5 a - c}$ (general procedure). To a solution of 2,6-diformylphenol $1(0.30 \mathrm{~g}, 2 \mathrm{mmol})$ in $\mathrm{EtOH}(20 \mathrm{ml})$ the appropriate metal salt $\left(\mathrm{NiCl}_{2}\right.$ or $\left.\mathrm{CuCl}_{2} \cdot 2 \mathrm{H}_{2} \mathrm{O}, 5 \mathrm{mmol}\right)$ was added. Mixture was slightly heated under stirring until salt completely dissolved followed by the dropwise addition of DBU (0.61 g, 4 $\mathrm{mmol})$ and solution of corresponding ethyl 2-[(2-aminophenyl) aminomethylidene]-1,3-dicarbonyl compound 2 (4 mmol) in EtOH $(10 \mathrm{ml})$. The reaction mixture was stirred for $5 \mathrm{~h}$ at room temperature and the precipitation formed was filtered. Products were purified by column chromatography (eluent $\mathrm{CHCl}_{3}$ : $\mathrm{EtOH}(5: 1)$ ).

Binuclear nickel(II) complex 5a. Prepared from ester 2b $(0.87 \mathrm{~g})$ and $\mathrm{NiCl}_{2}(0.65 \mathrm{~g})$. Yield $1.03 \mathrm{~g}(70 \%)$, mp 320-321 ${ }^{\circ} \mathrm{C}$ (orange powder). Found: C 52.36, H 3.90, N 7.55, Ni $16.00 \%$. $\mathrm{C}_{32} \mathrm{H}_{28} \mathrm{Cl}_{2} \mathrm{~N}_{4} \mathrm{Ni}_{2} \mathrm{O}_{5}$ requires $\mathrm{C} 52.16, \mathrm{H} 3.83, \mathrm{~N}$ 7.60, Ni 15.93. IR v $\mathrm{cm}^{-1}: 2994,2924,2855(\mathrm{C}-\mathrm{H}) ; 1668$ br $(\mathrm{C}=\mathrm{O}) ; 1642(\mathrm{C}=\mathrm{N}) ; 1601$, $1562(\mathrm{C}=\mathrm{C}) .{ }^{1} \mathrm{H}$ NMR $\left(\mathrm{CDCl}_{3}\right) \delta \mathrm{ppm}: 2.46,2.60$ (two m, both $6 \mathrm{H}$, $4 \mathrm{Me}$ ), 6.79 (br t, $J=7.6 \mathrm{~Hz}, 1 \mathrm{H}, \mathrm{Ar}), 7.13-7.15$ (m, 1H, Ar), 7.20, 7.29 (two br t, $J=7.6 \mathrm{~Hz}, 3 \mathrm{H}, \mathrm{Ar}$ ), 7.52-7.54 (m, 2H, Ar), 7.57 (br d, $J=8.3 \mathrm{~Hz}, 1 \mathrm{H}, \mathrm{Ar}$ ), 7.64 (dd., $J=7.6,1.7 \mathrm{~Hz}, 1 \mathrm{H}, \mathrm{Ar}$ ), 7.71 (br d, $J=7.9 \mathrm{~Hz}, 1 \mathrm{H}, \mathrm{Ar}$ ), 7.96 (dd, $J=7.4,1.7 \mathrm{~Hz}, 1 \mathrm{H}, \mathrm{Ar}$ ), 8.27, $8.28($ two s, both $1 \mathrm{H}, 2=\mathrm{CH}), 8.29(\mathrm{~s}, 2 \mathrm{H}, 2 \mathrm{H}-\mathrm{C}=\mathrm{N}), 10.59(\mathrm{~s}, 1 \mathrm{H}$, $\mathrm{OH})$.

Binuclear nickel(II) complex 5b. Prepared from ester 2c $(0.99 \mathrm{~g})$ and $\mathrm{NiCl}_{2}(0.65 \mathrm{~g})$. Yield $1.19 \mathrm{~g}(78 \%), \mathrm{mp} \mathrm{212-213}{ }^{\circ} \mathrm{C}$ (orange powder). Found: C 51.36, H 4.12, N 6.95, Ni $14.80 \%$. $\mathrm{C}_{34} \mathrm{H}_{32} \mathrm{Cl}_{2} \mathrm{~N}_{4} \mathrm{Ni}_{2} \mathrm{O}_{7}$ requires $\mathrm{C} 51.24, \mathrm{H} 4.05, \mathrm{~N} 7.03$, Ni 14.73. IR y $\mathrm{cm}^{-1}: 2983,2862(\mathrm{C}-\mathrm{H}) ; 1672$ br $(\mathrm{C}=\mathrm{O}) ; 1607(\mathrm{C}=\mathrm{N}) ; 1575(\mathrm{C}=\mathrm{C})$. ${ }^{1} \mathrm{H} \mathrm{NMR}\left(\mathrm{CDCl}_{3}\right) \delta \mathrm{ppm}: 1.37\left(\mathrm{t}, J=7.1 \mathrm{~Hz}, 6 \mathrm{H}, 2 \mathrm{OCH}_{2} \mathrm{CH}_{3}\right), 2.55$ $(\mathrm{s}, 6 \mathrm{H}, 2 \mathrm{Me}), 4.27\left(\mathrm{q}, J=7.1 \mathrm{~Hz}, 4 \mathrm{H}, 2 \mathrm{OCH}_{2} \mathrm{CH}_{3}\right), 6.75,7.14$, 7.24 (all br t, $J=7.5 \mathrm{~Hz}, 5 \mathrm{H}, \mathrm{Ar}$ ), 7.54, 7.60, 7.66, 7.91 (all dd, $J=$ $7.9,1.7 \mathrm{~Hz}, 6 \mathrm{H}, \mathrm{Ar}), 8.25(\mathrm{~s}, 2 \mathrm{H}, 2=\mathrm{CH}), 8.38(\mathrm{~s}, 2 \mathrm{H}, 2 \mathrm{H}-\mathrm{C}=\mathrm{N})$, $10.53(\mathrm{~s}, 1 \mathrm{H}, \mathrm{OH})$.

Binuclear copper(II) complex 5c. Prepared from ester $\mathbf{2 c}(0.99$ g) and $\mathrm{CuCl}_{2} \cdot 2 \mathrm{H}_{2} \mathrm{O}(0.85 \mathrm{~g})$. Yield $1.34 \mathrm{~g}(87 \%)$, mp $275-276{ }^{\circ} \mathrm{C}$ (dark brown powder). Found: C 50.51, H 4.08, Cu 15.80, N $6.97 \%$. $\mathrm{C}_{34} \mathrm{H}_{32} \mathrm{Cl}_{2} \mathrm{Cu}_{2} \mathrm{~N}_{4} \mathrm{O}_{7}$ requires $\mathrm{C} 50.63, \mathrm{H} 4.00, \mathrm{Cu} 15.76, \mathrm{~N}$ 6.95. IR v $\mathrm{cm}^{-1}: 2979(\mathrm{C}-\mathrm{H}) ; 1697$ br $(\mathrm{C}=\mathrm{O}) ; 1607(\mathrm{C}=\mathrm{N}) ; 1582,1540(\mathrm{C}=\mathrm{C})$.

Binuclear nickel(II) complex $5 \boldsymbol{d}$. $\mathrm{NiCl}_{2}(0.52 \mathrm{~g}, 4 \mathrm{mmol})$ was dissolved in EtOH and added dropwise to a solution of ester $\mathbf{3 d}$ $(1.44 \mathrm{~g}, 2 \mathrm{mmol})$ and pyridine $(0.32 \mathrm{~g}, 4 \mathrm{mmol})$ in $\mathrm{CHCl}_{3}(30 \mathrm{ml})$. The reaction mixture was stirred for $3 \mathrm{~h}$ at room temperature; the precipitation formed was filtered, crystallized from EtOH and dried to give complex 5d as crystal red powder. Yield $1.60 \mathrm{~g} \mathrm{(92 \% ),}$ mp 265-266 ${ }^{\circ} \mathrm{C}$. Found: C 45.29, H 2.89, F 12.67, N $6.30 \%$. $\mathrm{C}_{34} \mathrm{H}_{26} \mathrm{Cl}_{2} \mathrm{~F}_{6} \mathrm{~N}_{4} \mathrm{Ni}_{2} \mathrm{O}_{7}$ requires $\mathrm{C} 45.13, \mathrm{H} 2.90, \mathrm{~F} 12.60, \mathrm{~N}$ 6.19. IR $v \mathrm{~cm}^{-1}: 2953,2923(\mathrm{C}-\mathrm{H}) ; 1727,1703(\mathrm{C}=\mathrm{O}) ; 1637(\mathrm{C}=\mathrm{N}) ; 1603$, $1585(\mathrm{C}=\mathrm{C}) ; 1281-1156(\mathrm{C}-\mathrm{F}) .{ }^{1} \mathrm{H}$ NMR $\left(\mathrm{CDCl}_{3}\right) \delta \mathrm{ppm}: 1.37$ $\left(\mathrm{t}, J=7.1 \mathrm{~Hz}, 6 \mathrm{H}, 2 \mathrm{OCH}_{2} \mathrm{CH}_{3}\right), 4.32\left(\mathrm{q}, J=7.1 \mathrm{~Hz}, 4 \mathrm{H}, 2 \mathrm{OCH}_{2} \mathrm{CH}_{3}\right)$, $6.77(\mathrm{t}, J=7.9 \mathrm{~Hz}, 2 \mathrm{H}, \mathrm{Ar}), 7.23-7.30$ (m, 3H, Ar), 7.56, 7.60, 7.69, 
7.92 (all dd, $J=7.9,1.7 \mathrm{~Hz}, 6 \mathrm{H}, \mathrm{Ar}), 8.21(\mathrm{~s}, 2 \mathrm{H}, 2=\mathrm{CH}), 8.33$ (s, $2 \mathrm{H}, 2 \mathrm{H}-\mathrm{C}=\mathrm{N}), 10.33(\mathrm{~s}, 1 \mathrm{H}, \mathrm{OH}) .{ }^{19} \mathrm{~F} \mathrm{NMR}\left(\mathrm{CDCl}_{3}\right) \delta_{\mathrm{F}} \mathrm{ppm}: 93.87$ $\left(\mathrm{s}, 6 \mathrm{~F}, 2 \mathrm{CF}_{3}\right)$.

\section{Conclusions}

Perspective approach to the polydentate acyclic ligands 3 based on [1+2]condensation of 2,6-diformylphenol $\mathbf{1}$ with ethyl-2-[(2-aminophenyl)aminomethylidene]-1,3-dicarbonyl compounds 2a-d was reported. Compounds 3a-d can form both mono- and binuclear complexes with $3 \mathrm{~d}$ metal ions due to the presence of two coordination centers $\left(\mathrm{N}_{2} \mathrm{O}_{2}-\right.$ and $\mathrm{N}_{2} \mathrm{O}-$ ) in structure. Directed one-pot method of metal complexes synthesis is more efficient. Unequal structure of coordination units accounts for different conditions of complexes formation: mononuclear complexes $\mathbf{4}$ were shown to be formed as a result of $\mathrm{N}_{2} \mathrm{O}_{2}$-center coordination with the participation of 2,6-diformylphenol $\mathrm{OH}$-group in covalent bonding with the metal ion. In the case of binuclear complexes 5 two metal ions bind two $\mathrm{N}_{2} \mathrm{O}$-centers and counterions are participated in covalent bonding leaving free $\mathrm{OH}$-group. Diazomethines 3c,d exhibited the moderate inhibitor activity against growth of $M$. tuberculosis $\mathrm{H}_{37} \mathrm{Rv}$ (MIC $6.2 \mu \mathrm{g} / \mathrm{ml}$ ). Further work will be directed at the synthesis of supramolecular systems containing ions of different metals besides $3 \mathrm{~d}$ metals, e.g. $\mathrm{Pd}(\mathrm{II})$ or $\mathrm{Zn}(\mathrm{II})$, and their applied properties study (catalytic, photoluminescent, etc.).

Acknowledgements. This work was financially supported by the Presidium of Ural Branch of the Russian Academy of Sciences (Programs no. 12-T-3-1025, 12-П-3-1020).

\section{References}

1. Desbouis D., Troitsky I.P., Belousoff M.J., Spiccia L., Graham B. Coord. Chem. Rev. 2012, 256, 897-937.

2. DeSantis G., Luz J.G., Mitchell M., Wong C.-H., Wilson I.A. Science 2001, 294, 369-374.

3. Welter S., Brunner K., Hofstraat J.W., De Cola L. Nature 2003, 421, 54-57.

4. Wezenberg S.J., Kleij A.W. Angew. Chem., Int. Ed. Engl. 2008, 47, 2354-2364.
5. Mastalerz M., Schneider M.W., Oppel I.M., Presly O. Angew. Chem., Int. Ed. Engl. 2011, 50, 1046-1051.

6. Fedin M.V., Zhilina E.F., Chizhov D.L., Apolonskaya I.A., Aleksandrov G.G., Kiskin M.A., Sidorov A.A., Bogomyakov A.S., Romanenko G.V., Eremenko I.L., Novotortsev V.M., Charushin V.N. Dalton Trans. 2013, 42, 4513-4521.

7. Landee C.P., Turnbull M.M. Eur. J. Inorg. Chem. 2013, 22662285.

8. Angamuthu R., Byers P., Lutz M., Spek A.L., Bouwman E. Science 2010, 327, 313-315.

9. Holzwarth M.S., Plietker B. ChemCatChem 2013, 5, 16501679 .

10. Kudyakova Yu.S., Bazhin D.N., Burgart Ya.V., Saloutin V.I., Chupakhin O.N. Russ. J. Org. Chem. 2013, 49(3), 469-471.

11. Lyons C.T., Daniel T., Stack P. Coord. Chem. Rev. 2013, 257, 528-540.

12. Kudyakova Yu.S., Burgart Ya.V., Saloutin V.I. Chem. Heterocycl. Compd. 2011, 47(5), 558-563.

13. Kudyakova Yu.S., Burgart Ya.V., Slepukhin P.A., Saloutin V.I. Mendeleev Commun. 2012, 22, 284-286.

14. Hamaganova L.D., Fedotov A.N., Goldstein I.P., Domnina E.S., Abramova N.D. Zh. Fiz. Khim. 1990, 64, 575-577 (in Russ.).

15. Vigato P.A., Tamburini S. Coord. Chem. Rev. 2004, 248, 1717 2128.

16. Khanra S., Weyhermüller T., Bill E., Chaudhuri P. Inorg. Chem. 2006, 45, 5911-5923.

17. Jiang P., Guo Z. Coord. Chem. Rev. 2004, 248, 205-229.

18. Roy P., Dhara K., Manassero M., Ratha J., Banerjee P. Inorg. Chem. 2007, 46, 6405-6412.

19. Pryadeina M.V., Burgart Ya.V., Saloutin V.I., Slepukhin P.A., Kazheva O.N., Shilov G.V., D’yachenko O.A., Chupakhin O.N. Russ. J. Org. Chem. 2007, 43(7), 945-955.

20. Hunter C.A., Sanders J.K.M. J. Am. Chem. Soc. 1990, 112, 5525-5534.

21. Zahrt T.C., Song J., Siple J., Deretic V. Mol. Microbiol. 2001, 39, 1174-1185.

22. Organicum. Practicum on Organic Chemistry, Vol. 2. Moscow: Mir, 2008. 391 p. (in Russ.).

23. Opozda E.M., Śledziewska E., Łasocha W., Goubitz K., Schenk H. Polyhedron 1998, 17, 281-287.

24. Kudyakova Yu.S., Goryaeva M.V., Burgart Ya.V., Slepukhin P.A., Saloutin V.I. Russ. Chem. Bull., Int. Ed. 2010, 59(8), 1582-1593.

25. Jäger E.-G., Seidel D. Z. Chem. 1985, 25, 28-29.

26. Sheldrick G.M. Acta Crystallogr., Sect. A: Found Crystallogr. 2008, $A 64,112-122$. 